\title{
"Den som pekar på andras brister visar därigenom sina egna."
}

Genmäle till Malin Thor Tureby

\author{
Pontus Rudberg
}

DOI: $10.30752 /$ nj. 91374

Det finns ett ordspråk i Talmud som lyder "Kol haposel bemumo posel" (Den som pekar på andras brister visar därigenom sina egna, Kiddushin 7oa.) I artikeln "Den Judiska Kvinnoklubben (JKK) och de judiska flyktingarna under 1930- och I940-talen" i Nordisk judaistik (30:2) påstår historikern Malin Thor Tureby att det i tidigare forskning om den svensk-judiska flyktinghjälpen saknas berättelser om kvinnorna inom de judiska församlingarna. Med hänvisning till min avhandling gör hon gällande att jag bortsett från JKK och underskattat dess hjälpverksamhet. Thor Tureby menar att det har att göra med att medlemmarna i JKK "oftast inte satt på några ledande positioner i några av de kommittéer som fanns inom församlingarna" (Thor Tureby 20I9: 3). Inga av dess påståenden stämmer. Bland församlingens föreståndare och rabbiner fanns inga kvinnor, men kvinnor satt faktiskt på ledande positioner $\mathrm{i}$ ett antal kommittéer som deltog just i hjälpen till flyktingar (t.ex.
Understödsavdelningen, Barnavdelningen och Insamlingskommittén) i Mosaiska församlingen i Stockholm. Jag skriver exempelvis om Eva Warburg, Emelie Jungner, Olga Klein, Irma Fraenkel, Jeanette Ettlinger, Sara Gottfarb, Gerda Marcus, Kate Stangenberg och Hedvig Waldenström i detta sammanhang (se t.ex. Rudberg 2015: 48-9, 50, 52, 53-4, I38-9, I84, I86-7, 334; se även Hansson 2004: 159, I62, 226). Paradoxalt nog är det Thor Tureby som här osynliggör kvinnornas roll inom församlingens hjälpverksamhet.

Thor Tureby hävdar att jag tystar kvinnors berättelser genom att inte använda mig av JKK:s arkiv som finns i Judiska församlingens i Stockholm arkiv. I själva verket har jag använt arkivhandlingar från klubben som finns bevarade i andra delar av församlingens arkiv. Kvinnorna i klubben korresponderade med Mosaiska församlingen i Stockholm och dess olika kommittéer och klubben skickade sina årsberättelser till församlingen. Jag har använt 
både brev och årsberättelser, i flera falla samma källor som Thor Tureby använder i sin artikel. Hon påstår vidare att jag förbisett huvuddelen av klubbens hjälpverksamhet. Enligt henne har jag skrivit att JKK "främst hjälpte till inom ramen för församlingens hjälparbete genom att samla in medel till tyskjudiska barns sommarferievistelser i Sverige". Vad jag i själva verket skriver är: "Initially, it seems, the club was mainly involved in the MFST's relief work through its assistance in raising funds for the travel costs for German Jewish children who were coming to Sweden for their summer vacations" (Rudberg 2015: 60).

Thor Tureby utelämnar alltså det inledande ordet "Initially", vilket får det att framstå som att jag reducerar JKK:s aktiviteter till vad som bara var dess första steg. Vad hon inte talar om är att jag skriver att klubben förmodligen var den viktigaste av alla judiska föreningar och klubbar med avseende på dess insatser för flyktinghjälpen (Rudberg 20I5: 60). Inte heller nämner hon att jag sedan behandlar klubben, dess medlemmar och verksamhet, som gällde betydligt mer än resebidrag till "feriebarnen". Thor Tureby vill göra gällande att jag förbisett JKK:s hjälpverksamhet under krigsåren. Tvärtom nämner jag utifrån JKK:s årsberättelser bland annat de bridgeaftnar, välgörenhetsbasarer, soaréer, insamlingen för judiska barn i Sydfrankrike och annan hjälpverksamhet som även Thor Tureby skriver om. Beträffande perioden I942-I944 konstaterar jag: "With time and the developments of the terror in Europe, the efforts of the Jewish Women's Club intensified and it contributed to a number of different forms of aid" (Rudberg 2015: 298-9). I min avhandlings sammanfattning lägger jag särskild emfas vid JKK:s insatser:

The Jewish communities and their relief committees were not the only Jewish organizations in Sweden that tried to support Jews in Nazi-controlled Europe.
Other associations and clubs were also involved as they contributed to the MFST's fundraising and several of them through their own contributions. Especially the members of the Jewish Women's Club made important contributions as many of its members volunteered as refugee aidworkers, helping with the reception and care of arriving refugees and later survivors from Nazi Germany. (Rudberg 20I5:334)

Ett annat exempel på hur Thor Tureby vantolkar min forskning är när hon hävdar att jag återskapar "en berättelse om kvinnor som underordnade eller supplement till män och inte som självständiga individer och aktörer ...” På vilket sätt har jag gjort det? Jo, "genom att positionera kvinnorna som döttrar eller fruar till medlemmarna (männen)". Detta är en gemen tolkning. Jag pekade ut dessa band för att visa att familjemedlemmar i samma (borgerliga) skikt av församlingen var engagerade i hjälpverksamheten men ofta på olika områden och i olika organisationer. De nära relationerna gjorde det lättare för klubben att få tillgång till församlingshuset som lokal för klubbens möten och verksamhet, eller att planera och genomföra gemensamma aktiviteter. Jag tillmäter över huvud taget nätverk och relationer stor betydelse i avhandlingen och i det här fallet är de mycket relevanta. Thor Tureby gör precis samma poäng i sin artikel, men utan att nämna att den gjorts förut (s. I3).

Att Thor Tureby valt att misstolka och avfärda min forskning istället för att bygga vidare på den är givetvis hennes val. Avslutningsvis vill jag dock peka på två fall där hon kunde ha tagit hjälp av min forskning. Angående mottagandet av judiska feriebarnen från Tyskland skriver hon att det går "att konkludera att det var en verksamhet som initierades utifrån och som genomfördes i samarbete mellan några medlemmar från JKK och en av rabbinerna vid den 
Mosaiska församlingen i Stockholm" (Thor Tureby 20I9: IO). Jag har tidigare skrivit om "Sommarlyckan" som aktionen för feriebarnen kallades. I själva verket var andra Mosaiska församlingar i Sverige, och långt fler personer, än vad Thor Tureby framställer det som inblandade i verksamheten. Ett viktigt exempel är Sophie Michaeli som senare blev föreståndare för barnhemmet Tullgarn i Uppsala.

Det andra fallet är Jeanette Ettlingers resa till Barn- och Ungdomsalijahns (Kinder- und Jugendalijah, KJA) internationella kongress i Amsterdam i oktober 1937. Thor Tureby refererar felaktigt till en rapport från en annan KJA-kongress i Amsterdam två år tidigare (Thor Tureby 2019: I2). Hon menar att Ettlinger deltog som representant för JKK, men nämner inte ens att hon officiellt var där som representant för Mosaiska församlingen i Stockholm, och inte heller får vi veta vad hon sade på konferensen. Ettlingers rapport från konferensen I937 visar att hon representerade församlingen som ersättare för Marcus Ehrenpreis. I hans ställe tvingades hon meddela att församlingen inte ville förbinda sig till framtida penningbidrag till KJA. På kongressen argumenterade även Ettlinger, som själv var religiöst ortodox, för att flyktingbarn från ortodoxa hem även i fortsättningen skulle få traditionell religiös fostran och möjlighet att leva lagtroget. Men det var en fråga som även engagerade henne personligen (Ettlinger I938: I2-I6; Rudberg 2015: 49-50, 138).

Att ta spjärn mot tidigare forskning är ett vanligt sätt att motivera sin egen forskning. Men att göra det genom att avsiktligt ignorera och vantolka andras forskning är onödigt. Ingen tvivlar på att en undersökning av Judiska Kvinnoklubben är viktig. Thor Turebys försök att avfärda tidigare forskning gör mer skada än nytta på ett litet men spirande forskningsfält. Dessutom skymmer det sikten för hennes egna resultat.

\section{Referenser}

Ettlinger,Jeanette."Alijahkonferens i Amsterdam." Judisk Tidskrift II, nr I (januari 1938): I2-I6.

Hansson, Svante. Flykt och överlevnad - flyktingverksambet i Mosaiska Församlingen i Stockholm 1933-1950. Stockholm: Hillelförlaget, 2004.

Rudberg, Pontus. The Swedish Jerws and the Victims of Nazi terror, I933-1945. Studia Historica Upsaliensia 253. Uppsala: Acta Universitatis Upsaliensis, 2015.

Thor Tureby, Malin, "Den Judiska Kvinnoklubben (JKK) och de judiska flyktingarna under 1930och 1940-talen", Nordisk judaistik 30: 2 (2019): 3-26. 